\title{
PENGARUH MOTIVASI TERHADAP PEMBELIAN TELEPON SELULAR
}

\author{
Murwanto Sigit \\ Fakultas Ekonomi Universitas Islam Indonesia
}

\begin{abstract}
The competition among brands in mobile phone market is getting tight. Dominant players such as Nokia, Erricson, Motorolla, and Siemens now is being challenged by new players which offer a lower price with more attractive design. The purpose of this study is to analyze the effect of price, service availability, technology, and consumer self expression on the motivation to purchase Nokia mobile phone. Another objective is to determine whether there is a significant difference between male and female consumer on each factor. As many as 100 respondents are chosen from Economic Faculty UII students. So far, students is one of potential consumers for Nokia. Multiple regression and test of mean difference has been utilized to analyze data. The result shows that service and technology is significant, meanwhile price and consumer self expression is not significant. This result confirms the current image of Nokia as a good quality brand with stable market. There is significant different between man and woman consumers in all factors.
\end{abstract}

Keywords: service availability, service technology, self expression, motivation

\section{PENDAHULUAN}

Perkembangan komunikasi dengan menggunakan mobile phone atau handphone memang cukup cepat. Dimulai dengan teknologi IG (first generation) dimana kita dapat melakukan panggilan, disusul dengan 2G (second generation) dimana selain melakukan panggilan, kita juga dapat melakukan panggilan dan berkirim data (sms, gprs, mms, dll) dan yang termutakhir adalah teknlogi 3G (third generation) dimana saat ini komunikasi selular juga tidak hanya menggunakan audio semata, tetapi juga menggunakan visual.

Laju perkembangan teknologi yang sedemikian cepat tersebut juga harus diimbangi dengan kemampuan yang dimiliki oleh headset dan operator. Saat ini dipasaran banyak sekali handset telepon yang beredar. Dimana masing-masing vendor mengeluarkan beragam type yang bervariasi sesuai dengan fitur, fungsi, fasilitas tambahan yang bermacam-macam. Beberapa produk telepon selular yang beredar di pasaran Indonesia diantaranya adalah Nokia, Samsung, Siemens, Sony Ericson, Motorola, LG, dll.

Salah satu brand yang menguasai pasar Indonesia bahkan pasar dunia adalah Nokia, sebuah produk buatan Finlandia. Saat ini persaingan porsi penjualan telepon selular di dunia adalah sebagai berikut: 
Tabel 1: Urutan Pangsa Pasar Telepon Seluler Dunia (Tahun 2005)

\begin{tabular}{|c|c|}
\hline Merk & $\begin{array}{c}\text { Pangsa Pasar } \\
(\%)\end{array}$ \\
\hline Nokia & $30 \%$ \\
\hline Motorola & $17 \%$ \\
\hline Samsung & $13 \%$ \\
\hline LG & $6 \%$ \\
\hline Siemens \& Sony Ericson & $5,5 \%$ \\
\hline Merk-Merk Lain & $28,5 \%$ \\
\hline Total & $100 \%$ \\
\hline
\end{tabular}

Sumber: Gartner's Market Research Co. (www.kompas.co.id)

Dari tabel 1 di atas diketahui bahwa Nokia merupakan penguasa terbesar pasar telepon selular di dunia. Sedangkan merk lain seperti halnya Motorola, Samsung, LG, Siemens dan Sony Ericson berada di bawahnya.

Berdasarkan penelitian yang dilakukan oleh Gartner's Market Research Co, juga diketahui pangsa pasar Nokia di Indonesia sebagai berikut:

Tabel 2: Pangsa Pasar Telepon Seluler Nokia (Januari - Juli Tahun 2005)

\begin{tabular}{lc}
\hline \multicolumn{1}{c}{ Negara } & Pangsa Pasar (\%) \\
\hline Indonesia & $60 \%$ \\
Selandia Baru & $80 \%$ \\
Australia & $70 \%$ \\
\hline
\end{tabular}

Sumber: Gartner's Market Research Co. (www.kompas.co.id)

Dari tabel 2 di atas, dapat kita ketahui bahwa Nokia juga memiliki pangsa pasar yang terbesar di Indonesia.

Saat ini hampir setiap bulan Nokia meluncurkan produk terbarunya ke pasaran. Hal ini disebabkan karena permintaan dan inovasi yang tinggi. Dengan banyaknya type dari telepon selular Nokia di pasaran, hal ini tentunya membuat masyarakat dipermudah dalam menentukan type manakah yang cocok bagi mereka, hal ini dikarenakan dalam pemilihan suatu produk telepon selular, konsumen akan dipengaruhi oleh variable ekonomis, kemudahan, teknologi dan ekspresi. Kombinasi dari keempat variabel di atas, nantinya akan berdampak pada pemilihan type telepon selular merk Nokia.

Salah satu segmen konsumen yang senantiasa dibidik oleh Nokia adalah komunitas mahasiswa, hal tersebut dikarenakan mahasiswa merupakan suatu tingkatan manusia dimana pada komunitas tersebut masih banyak melakukan kreatifitas yang enerjik, baik dalam pikiran maupun perbuatan, sehingga mahasiswa senantiasa akan mengikuti tren perkembangan jaman yang ada. Hal ini sesuai dengan citra dari Nokia yang selalu memproduksi telepon selular yang mengikuti perkembangan jaman.

Mahasiswa dan kelompok usia muda merupakan salah satu pasar potensil bagi produk-produk handphone, termasuk Nokia. Umumnya mahasiswa adalah pribadi yang mempunyai tingkat mobile yang tinggi, menyukai model dan teknologi baru, namun memiliki daya beli yang tidak terlalu tinggi. Selain itu jumlah mahasiswa dan kelompok muda menempati porsi yang relatif besar di antara penduduk Indonesia. Oleh karena itu, perilaku membeli handphone dari para mahasiswa kemungkinan sangat dipengaruhi oleh harga, model, teknologi, dan keperluan untuk aktualisasi atau ekspresi diri.

Wulandari (2006) telah meneliti pengaruh fungsi sikap pelanggan terhadap jangka waktu pembelian kembali telepon selular merek Nokia di Surabaya". Penelitian ini bertujuan untuk mengetahui pengaruh fungsi sikap pelanggan terhadap jangka waktu pembelian kembali. Prosedur penelitian sampel diambil dari populasi konsumen yang membeli ponsel merek Nokia lebih dari satu kali, baik sebagai produk tambahan maupun sebagai produk pengganti. Teknik pengambilan sampel menggunakan metode non probability sampling, yaitu judgmental sampling dan accidental 
sampling. Teknik analisis yang digunakan dalam penelitian ini adalah regresi logistik, dengan uji Chi-square dan uji Wald. Dari hasil kuisioner yang telah disebarkan yang kemudian diolah dengan menggunakan program SPSS 13.00, diperoleh hasil bahwa dari uji chi-square maupun uji Wald, fungsi sikap pelanggan mempunyai pengaruh terhadap jangka waktu pembelian kembali baik secara simultan maupun parsial. Sehingga disimpulkan, bahwa fungsi sikap mempunyai pengaruh terhadap jangka waktu pembelian kembali, dan perusahaan perlu mengetahui peran atau fungsi sikap yang dimiliki konsumen terhadap suatu produk yang akan mempengaruhi waktu pembelian kembali. Sehingga perusahaan dapat mengidentifikasi segmen manfaat, mengembangkan produk baru, dan merencanakan serta mengevaluasi strategi promosi yang lebih baik.

Banyak ahli psikologi yang memberikan pengertian yang luas terhadap motivasi, misalnya Manulang (1981) memberikan pengertian motivasi atau motivition adalah pemberian motif, penimbulan motive atau hal yang menimbulkan dorongan atau keadaan yang menimbulkan dorongan. Moneir (1992) mendefinisikan motif adalah daya yang timbul dari dalam diri seseorang untuk dapat berbuat sesuatu. Motivasi kerja adalah suatu yang menimbulkan dorongan atau semangat kerja, atau dengan kata lain "pendorong semangat kerja". Beberapa faktor yang dapat mempengaruhi motivasi kerj, menurut J. Ravianto (1985) adalah atasan, rekan, sarana fisik, kebijaksanaan dan peraturan, inbalan jasa uang dan non uang, jenis pekerjaan dan tantangan.

Motivasi dapat dinilai sebagai suatu daya pendorong (driving force) yang menyebabkan orang berbuat sesuatu untuk menerapkan sesuatu. Chauman (1978), mengatakan bahwa motivasi menunjuk pada gejala yang melibatkan dorongan perbuatan terhadap tujuan tertentu. Selanjutnya
Chauman mengakui motivasi sebagai proses pembangkitan gerak dalam diri organisme. Motivasi dikemukakannya menjadi tiga fungsi yaitu: memberi tenaga dan mendorong tingkah laku, memberikan arah dan mengatur tingkah laku, dan menentukan tingkah laku. Gazda, et al. (1980)

mengatakan bahwa motivasi mengarahkan tingkah laku pada suatu tujuan. Senada dengan ini Nolker (1985), menganggap motivasi sebagai faktor penggerak yang dapat menyebabkan timbul perilaku tertentu.

Berdasarkan pemaparan latar belakang di atas, maka menarik untuk diteliti motivasi konsumen, khususnya mahasiswa, dalam membeli suatu produk telepon selular, khususnya merk Nokia. Merk tersebut dijadikan obyek penelitian karena menurut majalah Selular, telepon selular dengan merk Nokia menjadi pemimpin pasar dalam penjualan produknya dibandingkan merk lainnya di Indonesia (Majalah Selular, 2005).

Pertanyaan yang ingin dijawab oleh penelitian ini adalah: (1) Bagaimanakah pengaruh variabel-variabel yang meliputi variabel harga ekonomis, variabel kemudahan jangkauan pelayanan, variabel teknologi, dan varibel ekspresi diri konsumen baik secara simultan maupun parsial terhadap motivasi membeli handphone Nokia, serta (2) apakah ada perbedaan motivasi yang signifikan antara konsumen pria dan konsumen wanita.

\section{METODOLOGI PENELITIAN}

Penelitian yang digunakan oleh penulis adalah metode survey, yaitu pengumpulan informasi secara sistematik dari responden dengan maksud untuk memahami aspek perilaku dari populasi yang diteliti (Sekaran, 2000: 249). Penelitian dilakukan di wilayah Yogyakarta yang merupakan salah satu pasar handphone yang dinamis, di mana sampel diambil atas mahasiswa Fakultas Ekonomi Univeritas Islam 
Indonesia. Metode pengambilan sampel adalah nonprobability sampling, yaitu convenience sampling, yaitu mengumpulkan informasi dari anggota populasi yang mudah didekati dan didapatkan. Menurut Sekaran (2000: 277) ukuran sampel yang lebih besar dari 30 dan kurang dari 500 sudah cukup representatif untuk kebanyakan penelitian survey. Jumlah responden adalah 100 orang dengan kriteria berdomisili di Daerah Istimewa Yogyakarta yang masih dan pernah memakai Handphone merk Nokia lebih dari dua kali.

Data primer dikumpulkan dengan kuesioner dengan jawaban tertutup (closed questioner). Skala pengukuran merupakan kesepakatan yang digunakan sebagai acuan untuk menentukan panjang pendeknya interval yang ada dalam alat ukur, sehingga alat ukur bila digunakan dalam pengukuran akan menghasilkan data kuantitatif (Sugiyono, 2002:84). Skala yang dipakai adalah skala likert. Variabel diukur dengan skala likert 15 menggunakan jawaban "sangat setuju", "setuju, "netral", "tidak setuju”, "sangat tidak setuju". Tanggapan-tanggapan tersebut diberi bobot nilai dari 5 hingga 1 .

Sebuah model regresi berganda digunakan untuk mengetahui pengaruh variabel independne terhadap variabel dependen, sementara uji beda (Paired Simpel T Test) dilakukan untuk mengetahui perbedaan antara konsumen pria dan konsumen wanita. Data diolah dengan bantuan software SPSS 13.00 for windows. Pengujian asumsi klasik (multikolinearitas, autokorelasi, dan heterskedastisitas) dilakukan untuk menemukan model regresi yang terpercaya. Model regresi dirumuskan sebagai berikut:

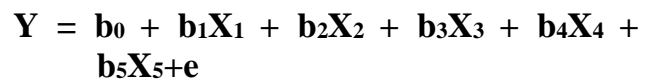

Dimana :

$\mathrm{Y}=$ keputusan pembelian telepon

$\mathrm{b}_{0}=$ konstanta regresi

$b_{1, . .} b_{5}=$ koefisien regresi
$\mathrm{X}_{1}=$ variabel ekonomis

$\mathrm{X}_{2}=$ variabel kemudahan

$\mathrm{X}_{3}=$ variabel teknologi

$\mathrm{X}_{4}=$ variabel ekspresi

\section{Uji Validitas dan Reliabilitas}

Uji validitas adalah untuk mengetahui kecermatan dan ketepatan suatu alat ukur dalam melakukan fungsi ukurnya. Uji validitas digunakan untuk memilih itemitem pertanyaan yang relevan untuk dianalisis. Uji validitas dengan melihat korelasi antar skor masing-masing item pertanyaan dengan skor total. Perhitungan validitas ini dilakukan dengan rumus teknik korelasi produk Moment Pearson, dengan rumus sebagai berikut (Suharsimi Arikunto. 2002:240).

$\mathrm{r}_{\mathrm{xy}}=\frac{n\left(\sum X-Y\right)-\left(\sum X\right)\left(\sum Y\right)}{\sqrt{\left[n\left(\sum X^{2}\right)-\left(\sum X\right)^{2}\right]\left[n\left(\sum Y^{2}\right)-(Y)^{2}\right]}}$

Dimana:

$\mathrm{r}_{\mathrm{xy}} \quad=$ Koefisien korelasi

$\mathrm{n}=$ Jumlah Responden

$\mathrm{X} \quad=$ Nilai masing-masing variabel

$\mathrm{Y} \quad=$ Total nilai kuesioner masingmasing responden

Uji reliabilitas menyatakan sejauh mana hasil pengukuran dapat dipercaya. Uji reliabilitas juga merupakan cara untuk melihat apakah alternatif ukur kuesioner yang digunakan konsisten atau tidak. Apabila suatu alat pengukur dipakai dua kali atau lebih besar dari hasil pengukuran yang diperoleh konsisten maka alat pengukur tersebut reabil.

Alat yang digunakan untuk mengukur tingkat signifikansi dari masingmasing variabel citra, kepuasan, nilai, loyalitas dalam hal ini adalah koefisien alpha. Koefisien reliabilitas dihitung dengan metode alpha, rumusnya antara lain sebagai berikut (Rangkuti, 2002; 76).

$\alpha=\left[\frac{K}{K-1}\right]\left[\frac{1-\sum \sigma i^{2}}{\sigma i^{2}}\right]$ 
Dimana:

$\alpha \quad=$ nilai reliabilitas alat ukur

$\mathrm{k} \quad=$ jumlah item satu pertanyaan

$\sum \sigma \mathrm{i}^{2}=$ jumlah varians masing-masing item

$\sigma \dot{i}^{2}=$ varians total

\section{HASIL DAN PEMBAHASAN}

Faktor-faktor yang mempengaruhi keputusan membeli handphone merk Nokia oleh konsumen nampak dalam hasil regresi di bawah. Regresi ini juga telah lolos dari pengujian asumsi klasik (autokorelasi, multikolinearitas, dan heteroskedastisitas).

$$
\begin{aligned}
\mathrm{Y}= & 0,153-0,201 \mathrm{X}_{1}+0,811 \mathrm{X}_{2}+0,504 \mathrm{X}_{3} \\
& \mathrm{~T}_{\text {test }}(-1,644) \quad(5.845) \quad(5.586) \\
& -0,178 \mathrm{X}_{4} \\
& (-1.786)
\end{aligned}
$$

$$
\mathrm{F}_{\text {test }} \quad: 15,613
$$$$
\mathrm{R}^{2} \quad: 0,576
$$

Adjusted $\mathrm{R}^{2}: 0,558$

$$
\text { DW test : 2,243 }
$$

Model regresi dalam penelitian ini dapat dikatakan cukup bagus (fit) sebagaimana nampak dalam $\mathrm{R}^{2}$ dan adjusted $\mathrm{R}^{2}$ yang relatif tinggi untuk suatu regresi dengan cross section data. $\mathrm{R}^{2}$ bernilai 0,576 , mempunyai arti bahwa variabel ekonomis, kemudahan, teknologi dan ekspresi mampu menjelaskan 57,6 \% variasi dari nilai keputusan membeli handphone. Demikian pula secara bersama-sama keempat faktor ini berpengaruh terhadap keputusan membeli, sebagai ditunjukkan oleh hasil uji $\mathrm{F}$ sebesar 32,200 (dengan $\alpha: 5 \%$ ).

Adapun secara individual variablevariabel di atas memiliki pengaruh yang berbeda-beda. Faktor ekonomis nampak tidak berpengaruh jika digunakan $\alpha$ : 5\%, namun berpengaruh jika ditingkatkan menjadi $\alpha$ : $10 \%$. Harga handphone merk Nokia yang secara umum relative tinggi (dibandingkan pesaingnya) tidak mempengaruhi keputusan membeli dari konsumen, sebagaimana Law of Demand yang berlaku pada bawang-barang normal. Hukum bahwa semakin murah maka semakin besar keputusan konsumen untuk membeli handphone tersebut tidak terlalu berlaku dalam hal ini. Harga tidak menjadi variable penentu dalam keputusan konsumen, tetapi variable lainlah yang diperhitungkan.

Harga bukan merupakan variable yang terlalu berpengaruh dalam pengambilan keputusan konsumen. Variabel kemudahan (X2 dan teknologi (X3) nampak signifikan berpengaruh pada $\alpha$ : $5 \%$ dan memiliki nilai parameter lebih tinggi dibandingkan lainnya. Hal ini mengukuhkan image yang telah terbangun pada masyarakat bahwa handphone Nokia memiliki keunggulan dalam fasilitas-fasilitas/fitur yang ditawarkan serta teknologi yang teruji. Kemudahan pengoperasian serta keunggulan teknologi memiliki pengaruh yang paling besar terhadap keputusan konsumen dalam memilih Nokia.

Ekspresi bukan merupakan variable penting yang mempengaruhi pembelian Nokia, sebagaimana nampak dalam hasil regresi di mana X4 tidak berpengaruh (pada $\alpha: 5 \%$, berpengaruh jika digunakan $\alpha: 10$ $\%)$. Kesederhanaan desain dan bentuk Nokia tidak mempengaruhi perilaku masyarakat untuk membeli handphone ini.

Sementara itu guna mengetahui perbedaan keputusan pembelian dari konsumen pria dan wanita berikut disajikan hasil analisis melalui analisis Paired Simpel T Test: 
Tabel 3: Hasil Uji Beda

\begin{tabular}{lrrrr}
\hline & \multicolumn{2}{c}{ Paired Differences } & \multicolumn{2}{c}{ prob } \\
\hline & Mean & Std. Deviation & $\mathrm{t}$ & \multicolumn{2}{c}{0,000} \\
ekonomis - jk & 2,61333 & 0,90357 & 28.922 & 0,000 \\
kemudahan - jk & 2,63000 & 0,83806 & 31.382 & 0.178 \\
teknologi - jk & 2,60667 & 0,86376 & 30.000 \\
ekspresi - jk & 2,52000 & 0,94438 & 26.684 & 0,000 \\
\hline
\end{tabular}

Keterangan :

Jk : Jenis kelamin

Dari hasil tabel di atas dapat diketahui bahwa $t$ test untuk semua variable signifikan, sehingga dapat disimpulkan bahwa terdapat perbedaan keputusan pembelian antara pria dan wanita dalam keputusannya membeli handphone Nokia.

\section{SIMPULAN DAN SARAN}

Motivasi masyarakat untuk membeli handphone merk Nokia ternyata dipengaruhi faktor kemudahan pengoperasionalannya serta teknologi yang diterapkannya. Harga dan ekspresi tidak berpengaruh terhadap motivasi konsumen untuk membeli handphone ini. Temuan ini memperkuat image yang sudah ada pada masyarakat tentang handphone merk Nokia sebagai handphone yang memiliki keunggulan dalam kenyamanan dan keandalan fungsional, sebagaimana tergambar dari variable kemudahan dan teknologi. Persaingan ketat dari produsen-produsen yang berbasis pada keunggulan harga, misalnya merk-merk baru dari China, ternyata tidak mempengaruhi motivasi konsumen untuk membeli handphone merk Nokia.

Dalam jangka pendek keunggulan non harga ini tentu saja merupakan keunggulan bersaing yang sangat menguntungkan, tetapi dalam jangka panjang faktor harga perlu dipertimbangkan. Handphone memiliki tingkat elastisitas harga permintaan yang tinggi sehingga perubahan harga akan sangat berpengaruh terhadap motivasi konsumen. Apalagi para produsen pesaing, terutama dari China, kini juga menawarkan produk-produk dengan teknologi dan kegunaan fungsional yang semakin tinggi tetapi dengan harga yang lebih murah.

Perbedaan perilaku antara konsumen wanita dan konsumen pria dapat menjadi inspirasi untuk pengembangan produk lebih lanjut. Handphone yang lebih dapat disesuaikan dengan jenis kelamin kemungkinan akan menjadi daya tarik bagi konsumen. Perbedaan untuk wanita dan pria ini dapat dilakukan baik dalam hal kemudahannya, teknologi dan fungsinya, desain dan ekspresinya, hingga harga jualnya.

\section{DAFTAR PUSTAKA}

Arikunto Suharmini, (1995), Manajemen Penelitian, Jakarta: Rineka Cipta.

Manulang, AC, (1990), Management Personalia, Jakarta: Ghalia Indonesia

Sekaran Uma, (2000), Research Methods For Business, Third Edition, New York: John Wiley \& Sons, Inc.

Sugiyono, (2002), Metode Penelitian Administrasi. Bandung : Alfabeta.

Fredi Rangkuti, (2002), Riset Pemasaran, Jakarta: Gramedia Pustaka Utama

Singgih Santoso, (2001), Metodologi Penelitian. Yogyakarta: BPFE 
Damodar Gujarati, (1999), Ekonometrika Dasar, terj. Jakarta: PT. Gelora Aksara Pratama Algifari, (2000), Metode Penerapan Regresi. Yogyakarta: AMP YKPN.

\section{Lampiran}

Pengujian Asumsi Klasik

Multikolinearitas

Tabel 4: Koefisien Uji Multikolinieritas

\begin{tabular}{llcc}
\hline & & \multicolumn{2}{c}{ Collinearity Statistics } \\
\cline { 3 - 4 } \cline { 3 - 4 } Model & & Tolerance & VIF \\
\hline 1 & X1 (Ekonomis) & 0,937 & 1.067 \\
& X2 (Kemudahan) & 0,854 & 1.171 \\
& X3 (Teknologi) & 0,849 & 1.177 \\
& X4 (Ekspresi) & 0,756 & 1.055 \\
\hline
\end{tabular}

Tabel 5: Hasil uji heterokedasitas

\begin{tabular}{cccccc}
\multicolumn{7}{c}{ Anova $^{\mathrm{b}}$} & \multicolumn{2}{c}{ Sig } \\
\hline Model & $\begin{array}{c}\text { Surn of } \\
\text { Squares }\end{array}$ & Df & Mean Square & F & $0,000_{\mathrm{a}}$ \\
\hline 1 Regression & 0,413 & 4 & 0,103 & 29.405 & \\
Residual & 0,334 & 95 & 0,004 & & \\
Total & 0,746 & 99 & & & \\
\hline
\end{tabular}

Tabel 6: Model Summaryb

\begin{tabular}{cccccc}
\hline Model & $\mathrm{R}$ & $\mathrm{R}$ Square & $\begin{array}{c}\text { Adjusted } \mathrm{R} \\
\text { Square }\end{array}$ & $\begin{array}{c}\text { Std.Error of the } \\
\text { Estimate }\end{array}$ & Durbin Watson \\
\hline 1 & $0,744^{\mathrm{a}}$ & 0,553 & 0,534 & 0,05925 & 2,243 \\
\hline Keterangan $:$ & & & & &
\end{tabular}

Keterangan :

$\mathrm{X}^{2}{ }_{\text {hitung }}=(\mathrm{TTS}) \mathrm{X}\left(\mathrm{R}^{2}\right) /(2)$

$\mathrm{X}^{2}$ hitung $=0,553 / 2 \times 0,746$

$\mathrm{X}_{\text {tabel }}^{2}$ sebesar 7,815 